\title{
Interaction of the Mite Aceria mangiferae with Fusarium mangiferae, the Causal Agent of Mango Malformation Disease
}

\author{
E. Gamliel-Atinsky, S. Freeman, A. Sztejnberg, M. Maymon, R. Ochoa, E. Belausov, and E. Palevsky
}

First and third authors: Department of Plant Pathology and Microbiology, Faculty of Agricultural, Food and Environmental Quality Sciences, The Hebrew University of Jerusalem, P.O. Box 12, Rehovot, 76100, Israel; first, second, and fourth authors: Department of Plant Pathology, Agricultural Research Organization (ARO), the Volcani Center, P.O. Box 6, Bet Dagan, 50250, Israel; fifth author: Systematic Entomology Laboratory, Bldg. 005, Room 137, Agriculture Research Service, United States Department of Agriculture, Henry A. Wallace Beltsville Agricultural Research Center, Beltsville, MD 20705, USA; sixth author: Microscopy Unit, ARO, The Volcani Center, Israel; and seventh author: Department of Entomology, Newe-Ya'ar Research Center, ARO, Ramat Yishay, 30095, Israel.

Accepted for publication 1 October 2008.

\begin{abstract}
Gamliel-Atinsky, E., Freeman, S., Sztejnberg, A., Maymon, M., Ochoa, R., Belausov, E., and Palevsky, E. 2009. Interaction of the mite Aceria mangiferae with Fusarium mangiferae, the causal agent of mango malformation disease. Phytopathology 99:152-159.

The role of the mango bud mite, Aceria mangiferae, in carrying conidia of Fusarium mangiferae, vectoring them into potential infection sites, and assisting fungal infection and dissemination was studied. Following the mite's exposure to a green fluorescent protein-marked isolate, conidia were observed clinging to the mite's body. Agar plugs bearing either bud mites or the pathogen were placed on leaves near the

demonstrating that the mite vectored the conidia into the apical bud. Potted mango plants were inoculated with conidia in the presence or absence of mites. Frequency and severity of infected buds were significantly higher in the presence of mites, revealing their significant role in the fungal infection process. Conidia and mite presence were monitored with traps in a diseased orchard over a 2-year period. No windborne bud mites bearing conidia were found; however, high numbers of windborne conidia were detected in the traps. These results suggest that $A$. mangiferae can carry and vector conidia between buds and assist in fungal penetration but does not play a role in the aerial dissemination of conidia between trees.
\end{abstract} apical buds of potted mango plants. Conidia were found in bud bracts only when both mites and conidia were co-inoculated on the plant,
Additional keyword: Eriophyidae, mite-fungal interactions.
Mango malformation is one of the most destructive diseases of this crop, occurring in most mango-producing regions worldwide $(7,17,30,32,33)$. The disease is characterized by malformation of vegetative growth and inflorescences, causing serious yield loss because malformed panicles do not bear fruit $(17,19)$. Fusarium mangiferae Britz, M. J. Wingf. \& Marasas, previously known as $F$. moniliforme J. Sheld. and later as $F$. moniliforme J. Sheld. var. subglutinans Wollenw. \& Reinking, has been identified as the causal agent of mango malformation disease $(4,5,12,20,21,26$, 31,41).

Little is known about the epidemiology of the disease, dissemination of conidia, location of infection sites, modes of infection, and colonization of plant tissue (30), or whether wounding is an obligatory condition for infection (32). Most of the infection studies were performed by wounding the plant tissue, assuming that a wound is necessary for fungal infection $(20,30,32,41)$. Despite this, two studies reported development of malformation symptoms following inoculations conducted without wounding of the plant tissue $(5,12)$.

The identity of the causal agent has been controversial for many years and other abiotic and biotic factors have been proposed as the primary causal agents of this disease $(8,23,24,27,44)$. The putative role of the mango bud mite Aceria (=Eriophyes) mangiferae Sayed (Eriophyidae) was partly based on the fact that eriophyoid mites are known to cause bud proliferation, "witches broom", and gall symptoms of inflorescences in other plants (42).

Corresponding author: S. Freeman; E-mail address: freeman@volcani.agri.gov.il

doi:10.1094/PHYTO-99-2-0152

(c) 2009 The American Phytopathological Society
In addition, herbivores may facilitate fungal infection by two main mechanisms: either by vectoring pathogen propagules or by creating wound sites for fungal penetration $(3,14)$, and a number of studies have reported association between herbivorous mites and fungal spores $(10,11)$. For example, the mite Brevipalpus phoenicis (Tenuipalpidae) was found in association with the fungal pathogen Elsinoe fawcettii Bitancourt \& Jenkins, the causal agent of citrus scab on sour orange (Citrus aurantifolia) in Honduras (10), but the significance of the mite in the epidemiology of the disease was not investigated. More research is needed in order to determine the role of herbivorous mites and, in particular, the eriophyoid mites as vectors of plant pathogens of a fungal nature.

A. mangiferae, initially described in Egypt (36), is commonly found within closed generative and vegetative mango buds in both malformed and healthy trees (39). These mites disseminate by wind from opening buds, land passively on a random tree, and actively find their way to mango buds. Thereafter, the mite settles and begins feeding by penetrating its stylets into the epidermal cell wall, creating shallow wounds of approximately 2 to $5 \mu \mathrm{m}$ in depth $(16,42)$. A. mangiferae was identified in both healthy and diseased trees and, in the absence of a direct correlation between the mite and mango malformation, it was proposed that mango malformation might result from an interaction between the mite and $F$. mangiferae $(34,39)$. When attempts to trap airborne conidia failed (30), a hypothesis emerged indicating that the bud mite serves as a vector for the fungal conidia (30). Summanwar and Raychaudhuri (40) recovered the pathogen from A. mangiferae's body, when sampled from diseased trees, and other research reported the isolation of Fusarium spp. from mites sampled from diseased and apparently healthy apical buds (18). Several studies 
have reported the production of symptoms after inoculating mango seedlings with bud mites collected from diseased trees $(18,20,24)$. For example, Manicom (20) indicated that spraying the pathogen's conidia on apical buds did not yield symptoms but, when mites were added, $8 \%$ of the apical buds were malformed, concluding that the presence of mites may have enhanced infection. An additional conclusion that can be drawn from this work is that the mites are capable of vectoring the fungal conidia into the apical buds. Although the studies described above present interesting information, it appears that the methods employed by these researchers could have led them to unfounded conclusions. For example, when transferring mites from diseased trees, contamination by conidia associated with the mites may have occurred; moreover, several studies lacked sufficiently robust evidence: for example, having numerical data and statistical analysis $(24,40)$. Therefore, from the present literature, it is still not clear that the two organisms interact in the epidemiology of this disease, partially due to a lack of suitable tools for tracking the fungal pathogen.

The main research goals of this study were to (i) determine whether A. mangiferae can carry $F$. mangiferae's conidia within or on the surface of its body, and assess its ability to vector the pathogen into the infection site; (ii) evaluate A. mangiferae's role in assisting the fungal infection process; and (iii) evaluate the role of $A$. mangiferae in the aerial dissemination of conidia.

\section{MATERIALS AND METHODS}

Plants, fungus, and bud mites. Two-year-old mango seedlings susceptible to malformation (cv. Maya grafted on rootstock 13/1), planted in 10-liter pots containing local red loam, were used in inoculation experiments. Phenology studies were conducted on cv. Haden in the Agricultural Research Organization (ARO) Volcani Center experimental mango orchard, Bet Dagan, coastal plain of central Israel. A local wild-type $F$. mangiferae isolate (MRC 7560) was used throughout the experiments (38). The monoconidial culture was maintained on potato dextrose agar (PDA) (Difco Laboratories, Detroit) at $25^{\circ} \mathrm{C}$. Conidial suspensions were obtained by adding sterile water to the cultured plates, mixing the suspension, and filtering it through a four-layered gauze pad. Seedling inoculations were performed by placing $20 \mu \mathrm{l}$ of conidial suspension $\left(5 \times 10^{6}\right.$ conidia/ml of water agar, $\left.0.1 \%\right)$ on apical buds and covering them overnight with plastic bags that were sprayed with water. For all mite-related experiments, $A$. mangiferae was collected directly from infested apical buds sampled from the Volcani experimental orchard. To prevent contamination and permit quantitative inoculation, apical buds were separated into bracts, inspected under a stereomicroscope at $\times 40$ magnification (Wild, Switzerland), and the number of bud mites on each bract were counted while other arthropods were removed using a fine brush.

Isolation and identification of the fungus from plant tissue were performed as follows. Bud bracts and stems (sectioned into pieces, $5 \mathrm{~mm}$ in length) were surface sterilized for $10 \mathrm{~s}$ in $70 \%$ ethanol, then $3.5 \mathrm{~min}$ in $3 \%$ sodium hypochlorate, and plated on a Fusarium-selective medium (25). After 6 days, fungal colonies that resembled Fusarium morphology were transferred to PDA, identified by morphology under a microscope, and verified by using a molecular polymerase chain reaction (PCR) method with specific primers (45). Isolation of the green fluorescent protein (gfp) isolate from plant tissue was conducted by plating material on PDA media amended with hygromycin at $50 \mu \mathrm{g} / \mathrm{ml}$ (see following section).

Gfp transformation. Plasmid pSK1019 was kindly provided by Dr. Seogchan Kang (Department of Plant Pathology, Pennsylvania State University). The plasmid contains the hygromycin B resistance $(h p h)$ gene under the Aspergillus nidulans trpC promoter and the EGFP gene in a 1.6-kb fragment under a Ch GPD promoter, cloned between EcoRI and HindIII sites of a pBHt2 vector (22). The vector was transformed into an Agrobacterium tumefaciens strain Eha105 by electroporation $(1.5 \mathrm{~K} \mathrm{~V}, 200 \mathrm{ohms}$, $50 \mu \mathrm{F})$. Transformation was carried out as previously described (22) with the following modifications: dilution of A. tumefaciens was conducted in the presence of acetosyringone; $200 \mu \mathrm{l}$ of coinoculated bacteria cells and conidia were plated directly onto $10 \mathrm{ml}$ of co-cultivation medium and incubated at $25^{\circ} \mathrm{C}$ for 2 days. Then, $10 \mathrm{ml}$ of selection medium containing hygromycin $\mathrm{B}$ at $100 \mu \mathrm{g} / \mathrm{ml}$, without the presence of moxalactum, was overlaid on each plate and incubated at room temperature for 5 to 7 days. Gfp transformants were isolated on PDA supplemented with hygromycin B $(50 \mu \mathrm{g} / \mathrm{ml})$.

DNA extraction was carried out as previously described (13). Southern hybridization was performed to determine T-DNA copy number of transformants. DNA was digested with HindIII and the products separated by electrophoresis on a $0.8 \%$ agarose gel in $0.5 \times$ Tris-acetate-EDTA (TAE) $(20 \mathrm{mM}$ Tris-acetate, $\mathrm{pH} 8.0$, and $0.5 \mathrm{mM}$ EDTA) buffer. Prehybridization, labeling, hybridization, and high-stringency washes of the membrane (Hybond-XL; Amersham Pharmacia, Buckinghamshire, UK) were performed as described according to the DIG High Prime DNA Labeling and Detection Starter Kit II (Roche Diagnostics, Mannheim, Germany). An 850-bp fragment from the hygromycin $h p h$ gene was labeled and used as a probe. Mitotic stability of transformants was tested as previously described (22). Transformants were cultured on PDA and transferred six times onto fresh PDA plates and also to PDA amended with hygromycin at $50 \mu \mathrm{g} / \mathrm{ml}$, and their resistance to hygromycin was tested to verify stability.

Gfp isolate pathogenicity. One of the six transformants, gfp-1, was used in two experiments to evaluate pathogenicity and symptom development on mango seedlings. For the first experiment, six potted plants were transferred to a growth chamber in September 2006, with $12 \mathrm{~h}$ of fluorescent light supplied by four 40-W, 2,300-lm daylight bulbs and constant temperature of $25 \pm$ $2{ }^{\circ} \mathrm{C}$. Three plants per isolate (bearing a total of 15 apical buds) were inoculated with either gfp-1 or wild-type isolates, as previously described. Two weeks postinoculation, buds were surface sterilized and plated for evaluation of fungal growth. For the second experiment, in March 2007, six potted plants per isolate were each inoculated with either the gfp-1 or the wild-type isolate. Half were incubated in a growth chamber under a day and night cycle of 29 and $21^{\circ} \mathrm{C}$ for 14 and $10 \mathrm{~h}$, respectively, for the induction of vegetative growth, and half were incubated for 1 month under a day and night cycle of 17 and $12^{\circ} \mathrm{C}$ and 10 and $14 \mathrm{~h}$, respectively, for the induction of flowering and symptom development. Three plants were water inoculated as controls.

Mites bearing fungal conidia. Mites collected from infested buds of various mango cultivars were exposed to the gfp- 1 isolate of $F$. mangiferae using two different methods. For the dipping method, 20 mango bud bracts, bearing approximately 100 bud mites per bract, were dipped for $5 \mathrm{~s}$ in the gfp- 1 suspension of $10^{6}$ conidia $/ \mathrm{ml}$. After allowing the bud bracts to dry, mites were removed with an ultrafine paint brush and mounted on doublesided sticky tape for microscopic observation. In the second method, 30 mites were placed on a $5-\mathrm{mm}^{2}$ PDA plug which was inoculated $48 \mathrm{~h}$ beforehand with the gfp-1 isolate. After $24 \mathrm{~h}$, mites were removed from plugs and inspected for conidia as described above.

Images of gfp-marked conidia were acquired using a confocal laser-scanning Olympus IX81 microscope (Tokyo). Confocal images were obtained via a PLAPO X40 WLSM immersion objective lens at an excitation wavelength of $488 \mathrm{~nm}$ (Argon laser), BA515-525 emission filter for gfp, and BA660IF emission filter for autofluorescence. Transmitted-light images were acquired using Nomarski differential interference contrast.

In order to determine whether the mite can ingest conidia and vector the pathogen within its gut, measurements of the diameter 
of A. mangifera's stylar feeding holes in the bract were documented using the low-temperature scanning electron microscopy (LT-SEM) technique and a Hitachi S-4100 scanning electron microscope (Tokyo) (2).

Vectoring of the pathogen by mites into apical buds. Potted mango plants were placed in a growth chamber at a constant temperature of $25 \pm 2{ }^{\circ} \mathrm{C}$ under diurnal 12-h light conditions. Two weeks before inoculation, the plants were fumigated twice with Dichlorvos (Divipan, 1,000 g/liter; Makhteshim-Agan, Omer, Israel), using a fumigator (Hagarin, Yavne, Israel) to ensure they were void of mites and insects. The base of the stem was ringed with a water-based adhesive (Rimifoot liquid; Rimi Chemical Co. Ltd., Petach Tikva, Israel) to prevent infestation by ambulant arthropods. Each plant was placed in a disinfected plastic cage and treated with one of the following four treatments. (i) One hundred mites were placed on two $5-\mathrm{mm}^{2}$ agar (PDA) plugs colonized with 3-day-old gfp-1 isolate. The plugs were then transferred to a leaf, at a distance of approximately $5 \mathrm{~cm}$ from an apical bud. (ii) One hundred mites were placed on two $5-\mathrm{mm}^{2}$ agar plugs (without the fungus) and then transferred to a distance of $5 \mathrm{~cm}$ from an apical bud as described above. (iii) Two $5-\mathrm{mm}^{2}$ agar plugs with the gfp- 1 isolate were placed at a distance of $5 \mathrm{~cm}$ from an apical bud. (iv) Untreated control, agar plugs without mites or fungus. Four apical buds were inoculated in each treatment and the experiment was repeated five times. Two days following inoculation, the apical buds were inspected with a stereomicroscope and the bud mites were counted. Then, the gfp conidia (if present) were washed from the bud bracts, plated on PDA amended with hygromycin at $50 \mu \mathrm{g} / \mathrm{ml}$, and, after 5 days, gfp colonies were enumerated. Conidia enumeration data underwent square root transformation, and data of bud mites were expressed as proportions of the original number of mites that were inoculated and transformed by arcsine square root before analysis. A $t$ test was used to determine significance of each mean from zero.

Bud mite assistance in fungal colonization. Potted mango plants were fumigated twice and placed in plastic cages as described above. Three days post-fumigation, plants were treated with one of the following treatments: (i) 40 apical buds were inoculated with gfp-1 conidia or (ii) 40 apical buds were inoculated with gfp- 1 conidia and then, after 4 days, inoculated with 50 mites/bud. The experiment was repeated twice in consecutive years, during 2006 and 2007. Twenty-one days postinoculation, buds were harvested, separated into bracts, disinfected, and plated on hygromycin-amended PDA medium, and fungal colonization was calculated. Two parameters were measured: the frequency of colonized buds, expressed as the ratio of colonized buds calculated from the total number of buds in the treatment; and severity of colonization, expressed as the average of colonized bracts per colonized bud. Statistical analysis of the first binary variable was performed using a $\chi^{2}$ test and that of the second parameter using a $t$ test, $P<0.05$.
Mite-fungal phenology. The presence of the pathogen and bud mites within apical buds was monitored during a 4-year survey in the Volcani orchard. Sixty 1-week-old apical buds (cv. Haden) were marked and, after 3 weeks, removed and examined in the laboratory. Each apical bud was dissected into bracts and inspected with a stereomicroscope for the presence of mites, then surface sterilized and plated on a Fusarium-selective medium for the detection of the pathogen. Percentages of buds populated with mites and the pathogen were calculated. Numbers of mites per apical bud were recorded for the period of May 2006 until December 2007. During December 2006 and March, November, and December 2007, there was no development of young branches in the orchard. For these samples, only the numbers of mites were enumerated. To determine whether presence of the fungus affected mite population density within the bud, mite population levels were compared in colonized and uncolonized buds by the fungus during May through October 2006 and 2007. The effects of sampling date, presence of the fungus, and their interaction were analyzed by two-way analysis of variance test. Because the interaction was not significant, the effect of the presence of the fungus on mite population density was determined by $t$ test.

Bud mite dissemination. Trapping of airborne mites was performed inside a growth chamber as follows. First, 12 branches from mite-infested trees in the orchard were pruned and their severed ends were washed in distilled sterilized water to prevent the milky sap from clogging the stem vessels. The branches were placed in water in 250-ml Erlenmeyer flasks and their openings were plugged with cotton and sealed with parafilm (American Can Co., Greenwich, CT). Using this methodology, the shoots continued to grow and the buds opened, allowing the mites to migrate in the airflow. Branches were placed in front of a fan in a wind tunnel apparatus (Fig. 1). When airflow moved from the narrow cylinder to the wider one, the velocity was reduced, thereby allowing the windborne eriophyoid mites to drop from the airflow onto the Vaseline-coated slides. To test the efficacy of this system, we used four heavily infested tomato plants with the tomato russet mite (TRM), Aculops lycopersici Massee, which belongs to the same family (Eriophyidae) as Aceria mangiferae and has similar body dimensions. The tomato plants were placed in the wind tunnel apparatus and, after 2 days, slides were inspected under a stereomicroscope. An average of $25.9 \pm 1.5$ TRMs were found on each slide, indicating that this method could be successfully used for detection of airborne eriophyids. The experiment to detect $A$. mangiferae was repeated four times with branches sampled in October 2005 and January, February, and March 2006.

For monitoring wind-blown mites under field conditions, a freely rotatable wind trap, made of 200-by-20-cm PVC pipe mounted on a pole attached to a wind vane, was placed in the Volcani experimental mango orchard surrounded by heavily infected trees (spaced 3 by $4 \mathrm{~m}$ apart) (9). A sheet of polycarbonate

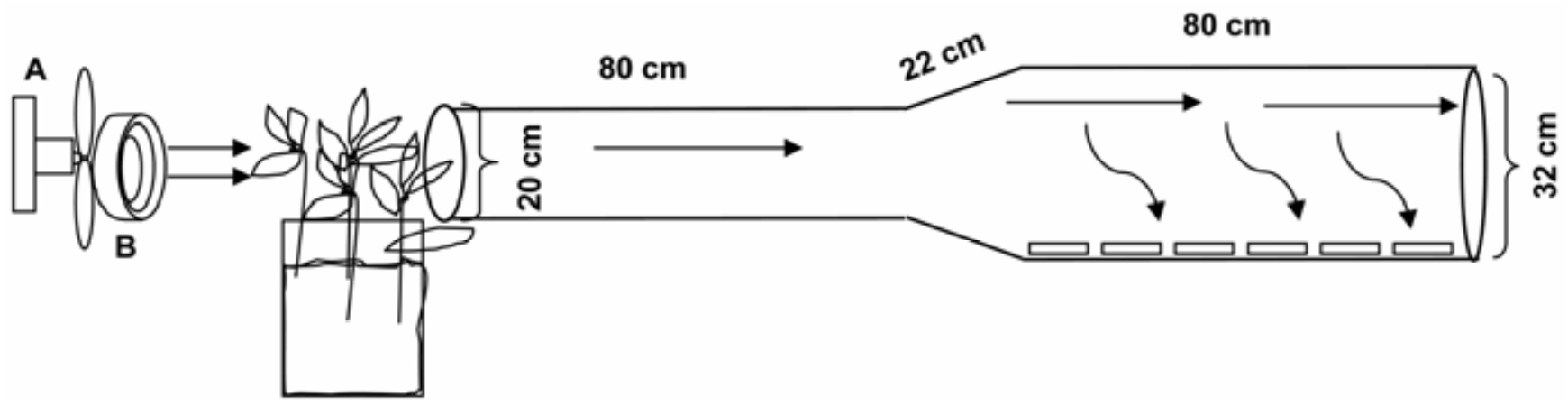

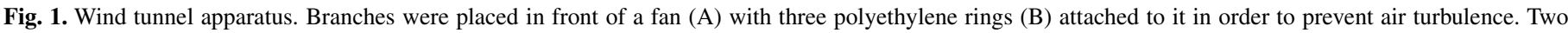

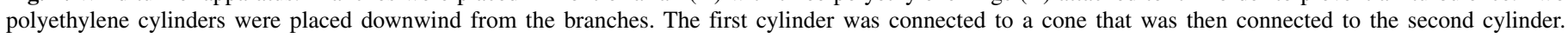
Twenty-six Vaseline-coated slides were placed on the bottom of the wider cylinder. Straight arrows indicate airflow direction. 
plastic ( 200 by $9 \mathrm{~cm}$ ) covered with 70 Vaseline-coated slides was inserted into the PVC pipe. Slides were replaced once a month from September 2005 until September 2006. After each exposure, slides were collected and examined for the presence of the mite under a stereomicroscope. Mites found on the slides were enumerated and examined for the presence of conidia at $\times 40$ using transmitted Nomarski differential interference contrast and plated on Fusarium-selective medium for fungal detection.

Conidial dissemination. Airborne conidia were monitored using a Burkard volumetric spore trap (Burkard Scientific Sales Ltd., Rickmansworth, United Kingdom). The trap was placed in the Volcani orchard, sucking in air continuously at a speed of 10 liters/min on Burkard adhesive 'Melinex' clear tape, for periods of 7 days, at the same site where the mite wind trap was located. The adhesive tape was then cut into seven 1-day pieces, washed with $5 \mathrm{ml}$ of sterile water, concentrated by centrifugation at $12,000 \mathrm{rpm}$ in a Hermle Z $400 \mathrm{~K}$ centrifuge (Hermle Labortechnik Wehingen, Germany), and $1 \mathrm{ml}$ was plated on five $\mathrm{Fu}$ sarium-selective medium plates for detection of $F$. mangiferae colonies. Five days later, colonies were enumerated and the pathogen was identified microscopically and verified by PCR. Data were collected continuously from May 2006 until December 2007, excluding the months of October through December in both 2006 and 2007, where only 1 week per month was sampled due to no or very low presence of source inoculum (airborne conidia). Total conidia per month were calculated by first determining mean conidia per day and then multiplying the result by the number of days per month.

\section{RESULTS}

Gfp transformation and pathogenicity. Six stable gfp transformants were obtained, five containing a single integrative copy of the plasmid, and one (gfp-3) containing two integrative copies of the plasmid (Fig. 2). An assessment of the mitotic stability of transformants determined that all of them maintained their hygromycin B resistance after six successive transfers.

In the first pathogenicity experiments, both the wild-type and the gfp- 1 isolates infected $27 \%$ of the buds. In the second experiment, half of the seedlings inoculated with either the wild-type or gfp-1 isolates (cultivated at 29 and $21^{\circ} \mathrm{C}$, day and night, respectively) started sprouting 3 months postinoculation, with vegetative malformation symptoms developing in all plants. The other half of the inoculated seedlings (exposed for 1 month to 17 and $12^{\circ} \mathrm{C}$ followed by 1 week at 29 and $21^{\circ} \mathrm{C}$, day and night, respectively) started to bloom and typical disease symptoms were again observed in all the plants. Noninoculated control plants remained healthy.

The role of mites in carrying the pathogen and vectoring it into apical buds. Inoculation of bud mites with a conidial suspension using the dipping method was not successful. When using

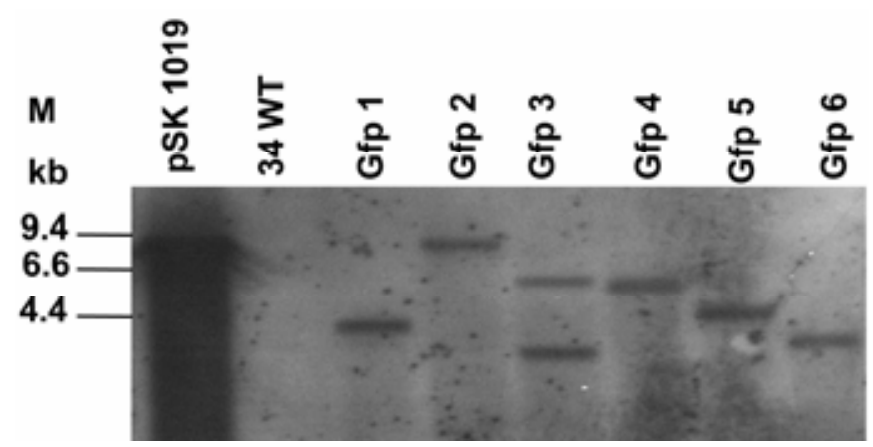

Fig. 2. Southern hybridization of HindIII-digested genomic DNA from the pSK 1019 plasmid, the wild-type isolate (34 WT), and six transformants (green fluorescent protein [gfp] 1 to 6) of Fusarium mangiferae. DNA size markers (M) in kilobase are included at the left. the second inoculation method (mites released on agar plugs colonized with the gfp-1 isolate), gfp fluorescing conidia were observed on the mites (Fig. 3). Conidia of the pathogen did not seem to cling to any particular part of the mites' bodies.

Images acquired by LT-SEM show a frontal dorsal view of $A$. mangiferae on mango apical bud scale tissue, with numerous punctures in the tissue caused by its feeding (Fig. 4A). The size of the holes, used in order to determine the external measurements of the stylets, varied between 0.4 and $0.7 \mu \mathrm{m}$ (Fig. 4B). The diameter of A. mangifera's stylets (all stylets combined) (Fig. 4C) measured $\approx 0.6 \mu \mathrm{m}$. These dimensions are an order of magnitude smaller than the width of $F$. mangiferae's conidia of 2.0 to $4.5 \mu \mathrm{m}$ (Fig. 4D), indicating that it is highly unlikely that the mite can ingest intact conidia.

Gfp-1 conidia were found in apical buds only when both bud mites and conidia were co-inoculated on the plant (Table 1). The numbers of gfp-1 conidia found in the apical buds in that treatment as well as the numbers of mango bud mites found in the apical buds in the two treatments where mites were inoculated were significantly different from zero (Table 1).

Bud mite assistance in fungal colonization. Frequency and severity of fungal colonization was significantly higher $(P<0.05)$ in buds inoculated with both bud mites and conidia than in buds inoculated with conidia alone, conducted in consecutive years during 2006 and 2007 (Fig. 5). In 2006, significantly higher colonization was recorded in the treatment with dual inoculations of both conidia and bud mites $\left(\chi_{1}^{2}=8.418, P=0.0037\right)$ (Fig. 5A). Severity of colonization in 2006 was also significantly higher $\left(\mathrm{t}_{48}=5.077, P<0.0001\right)$ in the combined mite and conidia treatment (Fig. 5B). Similar results were obtained in 2007, where significantly higher colonization rates were detected in the combined conidia and mite inoculations $\left(\chi^{2}{ }_{1}=4.082 ; P=0.043\right)$, including more severe colonization rates $\left(\mathrm{t}_{52}=2.684 ; P<0.009\right)$.

Role of $A$. mangiferae in aerial dissemination of conidia. $A$. mangiferae and $F$. mangiferae were present in apical buds throughout the year. More than $67 \%$ of all apical buds in each sample were populated with bud mites, whereas the frequencies of $F$. mangiferae were much lower (Fig. 6). Average numbers of A. mangiferae per apical bud varied from $18 \mathrm{mites} / \mathrm{bud}$ in May and December 2006 and in March 2007 to a peak of 62 and 56 mites/bud in July 2006 and October 2007, respectively. On average, for the 10 sampling periods in both years, 50 mites/bud were

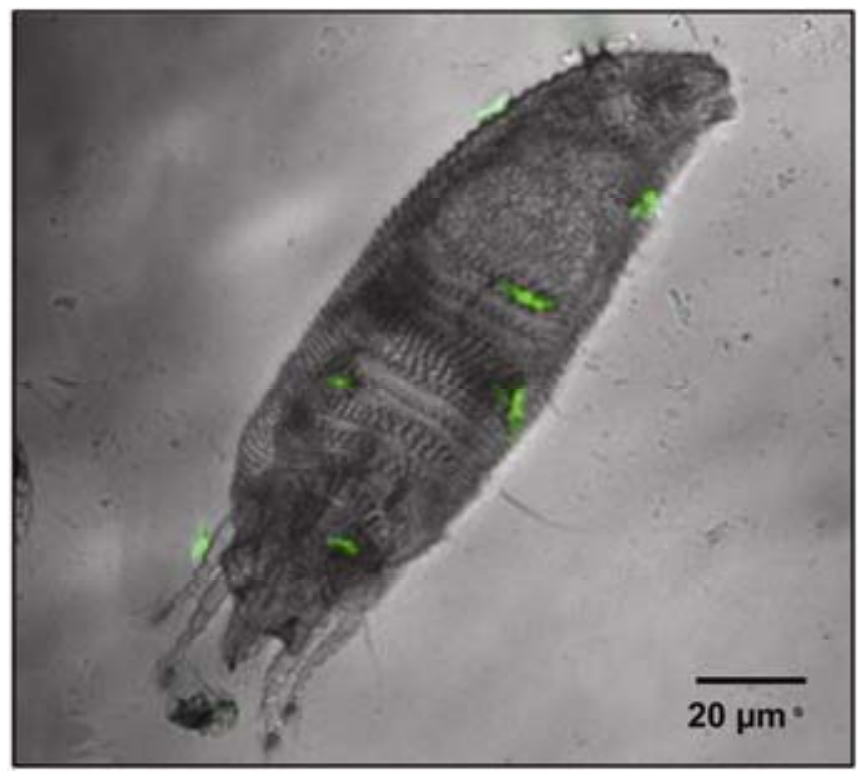

Fig. 3. Mango bud mite, Aceria mangiferae, bearing gfp-1 conidia of $F u$ sarium mangiferae (shown in green), the causal agent of mango malformation disease. 
detected in buds colonized by the fungus, which was significantly higher than that of 33.6 detected in buds not colonized by the fungus $\left(\mathrm{t}_{586}=3.731 ; P=0.0002\right)$.

In the wind tunnel apparatus, 2, 12, 7, and 5 mango bud mites were detected during the four trials. A number of viable $F$. mangiferae conidia were also recovered $(1,3,1$, and 1 , respectively) but none were found on the trapped windborne mites. Thirteen $A$. mangiferae were captured using the wind-mite trap in the Volcani orchard from September 2005 to September 2006, none bearing $F$. mangiferae conidia on their bodies. In contrast, high inoculum density of $F$. mangiferae conidia trapped in a volumetric spore trap was recorded in the Volcani orchard, with a peak in airborne conidial numbers during May and June in both 2006 and 2007 (Fig. 7). The peak in aerial dissemination corresponded with the peak of malformed inflorescences in the orchard.

\section{DISCUSSION}

The results of this study shed light on the involvement and role of A. mangiferae in mango malformation disease, an issue of
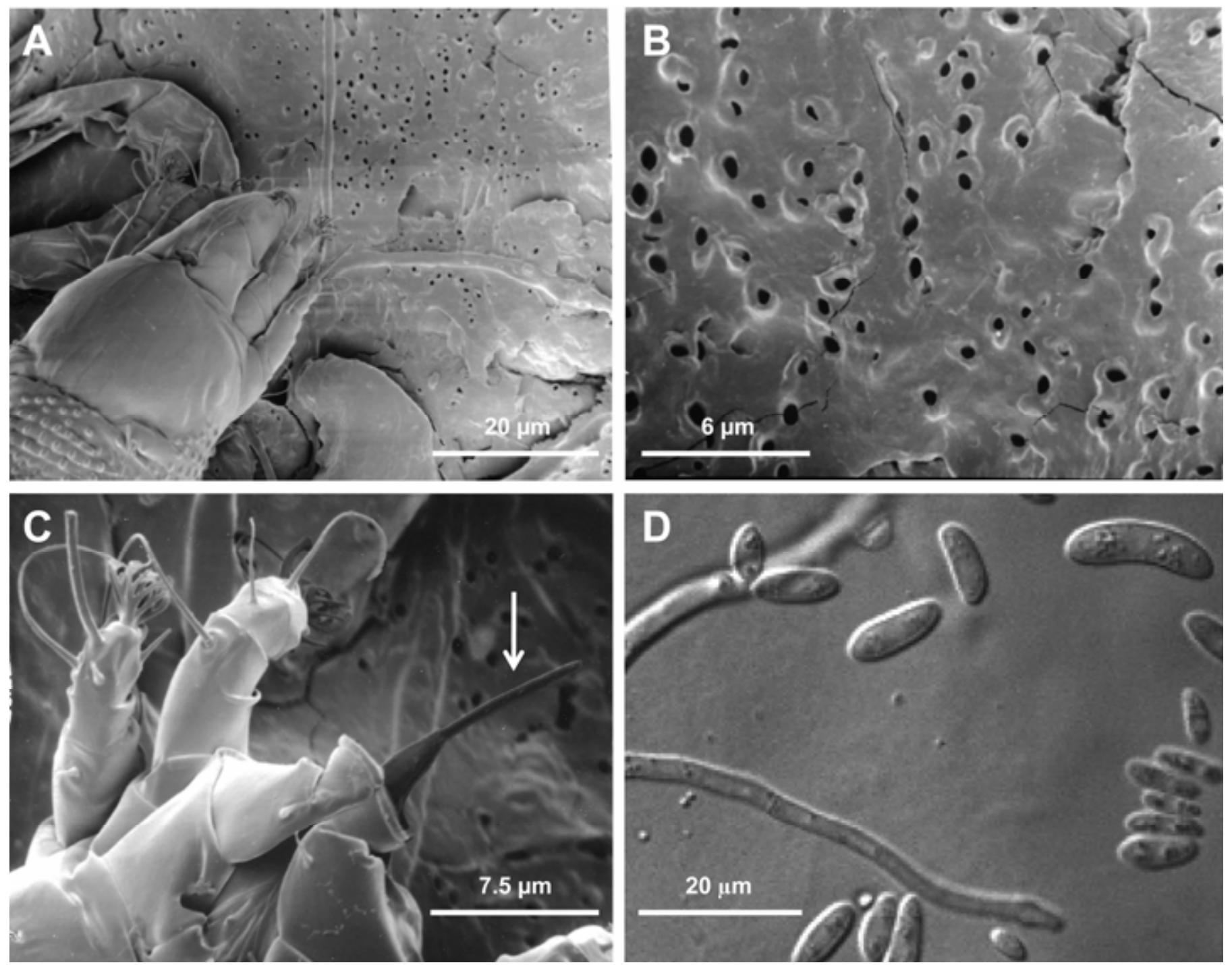

Fig. 4. Mango bud mite, Aceria mangiferae, with respective puncture holes in bud tissue. Low-temperature scanning electron microscopy image of A, A. mangiferae's propodosoma and stylar puncture holes in bud tissue resulting from mite feeding; $\mathbf{B}$, area of enlarged punctures showing apertures of 0.4 to $0.7 \mu \mathrm{m}$ in diameter; C, A. mangiferae's stylets, marked by a white arrow; and D, confocal laser-scanning microscope of conidia and hyphae of the fungal pathogen Fusarium mangiferae.

TABLE 1. Average number of Aceria mangiferae and green fluorescent protein (gfp) marked Fusarium mangiferae's conidia per apical mango bud ${ }^{\mathrm{a}}$

\begin{tabular}{|c|c|c|c|c|c|c|}
\hline \multirow[b]{2}{*}{ Inoculation with } & \multicolumn{3}{|c|}{ Bud mites } & \multicolumn{3}{|c|}{ Gfp conidia } \\
\hline & Average & SE & $P^{\mathrm{b}}$ & Average & SE & $P^{\mathrm{c}}$ \\
\hline Mites with gfp conidia & 1.4 & 0.71 & 0.017 & 0.45 & 0.20 & 0.014 \\
\hline Mites only & 1.75 & 0.81 & 0.005 & 0 & $\ldots$ & $\ldots$ \\
\hline Gfp only & 0 & $\ldots$ & $\ldots$ & 0 & $\ldots$ & $\ldots$ \\
\hline Untreated control & 0 & $\ldots$ & $\ldots$ & 0 & $\ldots$ & $\ldots$ \\
\hline
\end{tabular}

a Twenty buds per treatment were evaluated on potted mango plants. SE = standard error.

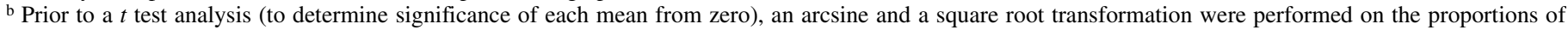
mites (from the 100 mites that were inoculated).

c Prior to a $t$ test analysis (to determine significance of each mean from zero), data underwent a square root transformation. 
controversy for many years (30). We focused on three stages of the disease cycle: reaching the infection site, colonization, and aerial dissemination. For each stage, the question of whether the mite assists the fungal pathogen was addressed. In this study, a gfp-transformed isolate of $F$. mangiferae was used as a tool which distinguished this work from previous studies. This marked strain allowed us to avoid confusion with natural infections of the pathogen and also to reduce the experimental time needed for detection of fungal colonization as opposed to waiting for symptom

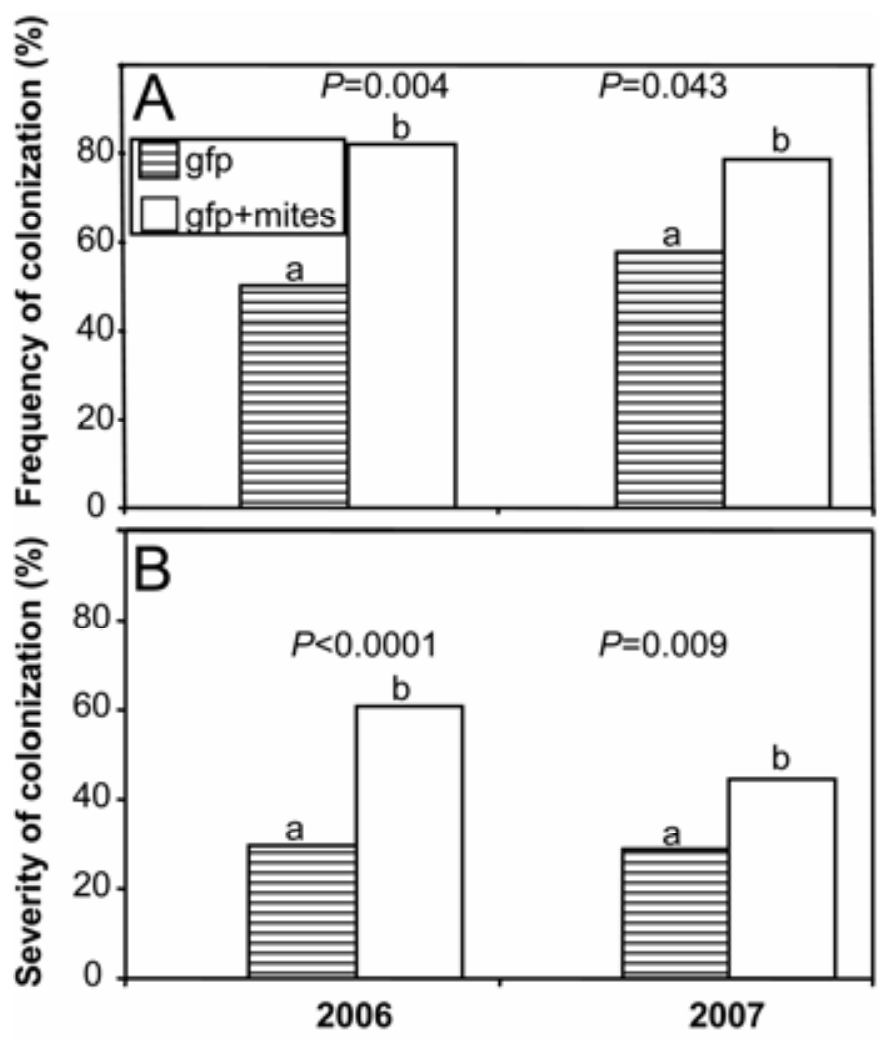

Fig. 5. A, Frequency and B, severity of Fusarium mangiferae gfp-1 isolate colonization in inoculated mango apical buds with and without the presence of bud mites performed twice during 2006 and 2007. Severity of colonization was measured as the frequency of infected scales per infected bud. Statistical analysis of the binary variable in A was calculated using a $\chi^{2}$ test. Statistical analysis of the continuous variable in $\mathrm{B}$ was calculated using a $t$ test. Significance refers to each pair of means per year separately. Treatments with different letters are significantly different $(P<0.05)$. development. The gfp-1 isolate produced and used throughout the study was stable and infective, causing typical disease symptoms in inoculated plants.

Eriophyoid mites effectively transmit plant viruses by ingesting the plant pathogen into their gut $(15,37)$. However, with the $A$. mangiferae $-F$. mangiferae interaction, morphological measurements demonstrated clearly that the conidia are too large to be ingested, thereby allowing only external bearing by the mite. A similar conclusion was reached by Oldfield and Proeseler (28), who indicated that the minute diameter of eriophyoid mouthparts may preclude ingestion of larger plant pathogens and that some viruses are too long for the mite to ingest, suggesting that a specific orientation of the virus is required for it to be passed through the oral opening of its vector. Eliminating the possibility of the mite carrying the conidia within its body reinforces the importance of our results, demonstrating how A. mangiferae can, under laboratory conditions, bear conidia on its body. By using gfp-labeled conidia, we have shown unequivocally that $A$. mangiferae can carry $F$. mangiferae, unlike previous studies of $A$. mangiferae sampled from diseased apical buds $(18,40)$ which did not specifically identify the fungus as $F$. mangiferae and could not exclude contamination of mites by unidentified Fusarium spp. during transfer from malformed buds to PDA plates and to microscope slides.

Although both the fungus and the mite are disseminated aerially and randomly land on the tree, only the mite has the capacity to actively seek out, discover, and successfully colonize the apical bud. This led us to examine the feasibility of conidial transport on the body of the mite from their arbitrary landing sites on leaves into buds, apparently their exclusive infection sites. Conidia were observed within apical buds only when an adjacent leaf was inoculated with both mites and conidia, and buds of the other control treatments were devoid of conidia; therefore, we conclude that the only way for the conidia to reach the apical bud in these controlled seedling inoculation experiments is via the mite as a vector. These results are in agreement with those of Manicom (20), who obtained enhanced malformation symptoms on seedlings by attaching malformed buds containing mites and fungus as opposed to a conidial spray alone.

After reaching the infection site, conidia penetrate the host. This process takes place inside the apical bud-a common habitat for both the mite and the fungus (1,39). As in previous studies, we observed high frequencies of apical buds populated with $A$. mangiferae throughout the year $(29,34,44)$, and higher numbers of mites in buds colonized by the fungus compared with noncolonized ones (18). This positive correlation between the two organisms could be explained, among other possible explanations,

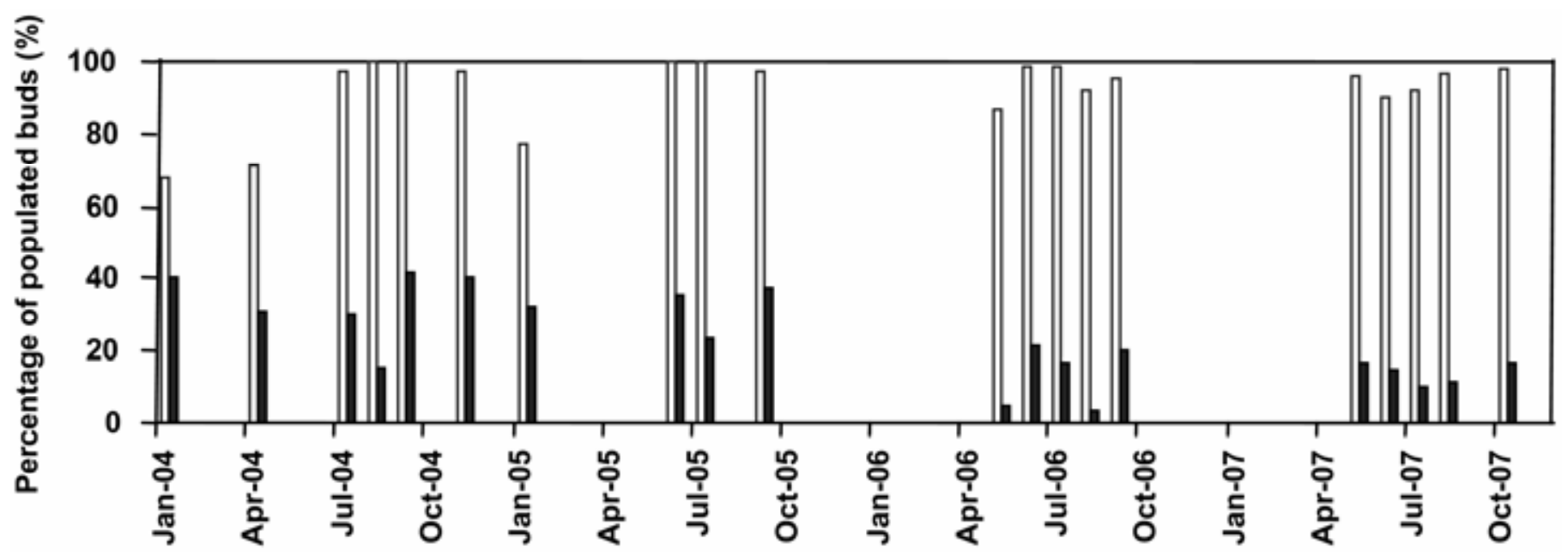

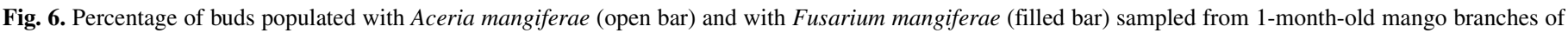
cv. Haden from the Volcani experimental orchard, Bet Dagan during the years 2004-2007. 


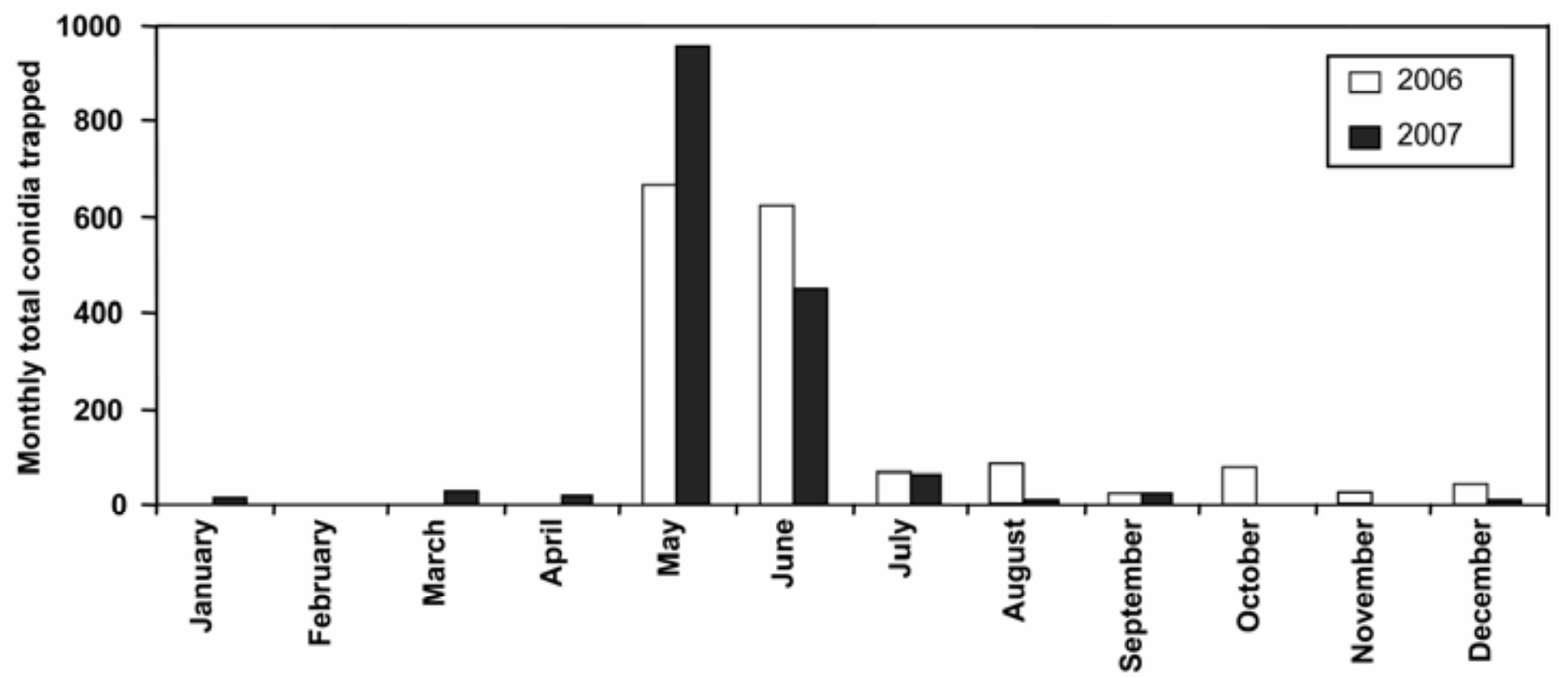

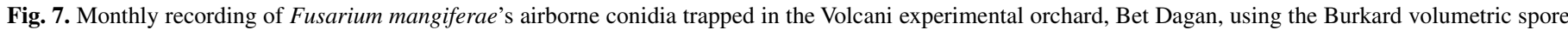
trap over 7-day periods during 2006 and 2007.

by either the fungus providing a better habitat for the mite or the mite providing more attractive infection sites for the fungus. Positive interactions between mites and disease are also suggested by a positive correlation between numbers of mites in malformed tissue and severity of disease in some previous studies (35), although this correlation is not present in some other studies (34).

One possible mechanism for positive interactions between $A$. mangiferae and $F$. mangiferae is that mites increase in the success of fungal infection; however, the results of previous studies regarding this mechanism have been inconclusive $(18,20)$, perhaps because humidity was insufficient to support effective infection by $F$. mangiferae (24). Our data from experiments on potted plants showed clearly that the presence of $A$. mangiferae inside the buds increased frequency and severity of bud colonization by the pathogen. However, although mite feeding sites may facilitate fungal germ tube penetration into the bud tissue, they are not necessary for infection, because high frequencies of infected buds resulted from inoculations made in the absence of the mites or artificial wounds.

We also tested the hypothesis that the bud mite serves as a vector for the dissemination of fungal conidia (30), which has been proposed previously because several attempts to trap windborne conidia failed $(30,31)$. Unlike previous studies of air dispersal of $F$. mangiferae conidia, we used a modified technique (washing and plating the Burkard rotary trap band, over selective medium plates) to successfully determine the conidial dispersal pattern under field conditions over a 2-year period. Attempts to capture airborne mites in the orchard over a 1-year period were also partially successful, despite the limits imposed by the biology of the mite. Unlike eriophyid vagrant mites that inhabit leaves and disseminate in the air in high numbers (6), airborne population levels of $A$. mangiferae are relatively low because they inhabit closed apical buds and disperse from them when bud break commences, each bud opening independently (43). None of the airborne $A$. mangiferae that were trapped in the orchard and in the growth chamber bore conidia on their bodies. In addition, aerial conidia were abundant in the absence of mites. Thus, it appears that the mites do not contribute substantially to the conidial dissemination process and that conidia can be passively dispersed through the air from malformed panicles. The mite and the conidia apparently "meet" after landing on the tree canopy, when the mite makes its journey toward the apical bud.
In summary, the interaction between $A$. mangiferae and $F$. mangiferae, the causal agent of mango malformation disease, has been suggested for many years but never thoroughly studied. In this research, we demonstrated that $A$. mangiferae can bear fungal conidia externally on its body, transport conidia between apical buds on infected trees, and so facilitate fungal colonization, but that the mite is unlikely to play a role in transferring conidia between trees. Our results provide a better understanding of the nature of the interaction and the potential for A. mangiferae to enhance disease frequency and severity in the orchard. These epidemiological data may assist in developing an improved control program for mango malformation disease.

\section{ACKNOWLEDGMENTS}

This research was supported in part by grant no. 132-0972 from the Chief Scientist of the Israeli Ministry of Agriculture, and by the Bureau for Economic Growth, Agriculture, and Trade, U.S. Agency for International Development, under the terms of the Middle East Regional Cooperation Program Award No. TA-MOU-02-M21-030, awarded to S. Freeman. We thank H. Voet (Hebrew University) for advice in the statistical analyses; J. Pena (University of Florida) and E. Erbe and C. Pooley (EMU-ARS, United States Department of Agriculture [USDA]) for their assistance in the collection and preparation of the material and SEM images; E. McDonald, G. Millerand, N. Vandenberg (USDA), U. Gerson (Hebrew University), D. Shtienberg (ARO), and J. Amrine (West Virginia University) for their critical reviews of this manuscript; and A. Zveibel, Y. Denisov, and M. Sharon (ARO) for technical assistance.

\section{LITERATURE CITED}

1. Abou Awad, B. A. 1981. Ecological and biological studies on the mango bud mite, Eriophyes mangiferae (Sayed), with description of immature stages (Eriophyoidea: Eriophyidae). Acarologia 22:145-150.

2. Achor, D. S., Ochoa, R., Erbe E. F., Aguilar, H., Wergin, W. P., and Childers, C. C. 2001. Relative advantages of low temperature versus ambient temperature scanning electron microscopy in the study of mite morphology. Int. J. Acarol. 27:3-12.

3. Agrios, G. N. 1980. Insect involvement in the transmission of fungal pathogens. Pages 293-324 in: Vectors of Plant Pathogens. K. F. Harris and K. Maramorosch, eds. Academic Press, New York.

4. Britz, H., Steenkamp, E. T., Coutinho, T. A., Wingfield, B. D., Marasas, W. F. O., and Wingfield, M. J. 2002. Two new species of Fusarium section Liseola associated with mango malformation. Mycologia 94:722730 . 
5. Chakrabarti, D. K., and Ghosal, S. 1989. The disease cycle of mango malformation induced by Fusarium moniliforme var. subglutinans and the curative effects of mangiferin-metal chelates. J. Phytopathol. 125:238246.

6. Childers, C. C., and Achor, D. S. 1999. The eriophyoid mite complex on Florida citrus (Acari: Eriophyidae and Diptilomiopidae). Proc. Fla. State Hortic. Soc. 112:79-87.

7. Crookes, C. A., and Rijkenberg, F. H. J. 1985. A literature review of the distribution, symptomology, cause and control of mango blossom malformation. S. Afr. Mango Grow. Assoc. Res. Rep. 5:15-24.

8. Denmark, H. A. 1983. Eriophyes mangiferae (Sayed) a pest of mango (Acarina: Eriophyidae). Fla. Dep. Agric. Consum. Serv. Div. Plant Ind. Entomol. Circ. 254.

9. Duffner, K., Schruft, G., and Guggenheim, R. 2001. Passive dispersal of the grape rust mite Calepitrimerus vitis Nalepa 1905: (Acari, Eriophyoidea) in vineyards. Anz. Schaedlingskd. 74:1-6.

10. Evans, G. A., Cromroy, H. L., and Ochoa, R. 1993. The Tenuipalpidae of Honduras (Tenuipalpidae: Acari). Fla. Entomol. 76:126-155.

11. Evans, G. A., Cromroy, H. L., and Ochoa, R. 1998. The family Tenuipalpidae in Bermuda (Prostigmata:Acari). Fla. Entomol. 81:167170.

12. Freeman, S., Maimon, M., and Pinkas, Y. 1999. Use of GUS transformants of Fusarium subglutinans for determining aetiology of mango malformation disease. Phytopathology 89:456-461.

13. Freeman, S., Pham, M., and Rodriguez, R. J. 1993. Molecular genotyping of Colletotrichum species based on arbitrarily primed PCR, A+T-rich DNA and nuclear DNA analyses. Exp. Mycol. 17:309-322.

14. Hatcher, P. E., and Paul, N. D. 2001. Plant pathogen-herbivore interactions and their effects on weeds. Pages 193-218 in: Biotic Interactions in Plant-Pathogen Associations. M. J. Jeger and N. J. Spence, eds. CAB International, Wallingford, UK.

15. Jones, A. T., Kumar, P. L., Saxena, K. B., Kulkarni, N. K., Muniyappa, V., and Waliyar, F. 2004. Sterility mosaic disease-the "green plague" of pigeonpea. Advances in understanding the etiology, transmission and control of a major virus disease. Plant Dis. 88:436-445.

16. Krantz, G. W., and Lindquist, E. E. 1979. Evolution of phytophagous mites (Acari). Annu. Rev. Entomol. 24:121-158.

17. Kumar, J., Singh, U. S., and Beniwal, S. P. S. 1993. Mango malformation: One hundred years of research. Annu. Rev. Phytopathol. 31:217-232.

18. Labuschagne, T. I., Joubert, M. H., and Steyn, A. 1993. Role of the mango bud mite, Aceria mangiferae (Sayed) in mango malformation. Inligtingsbull. Inst. Trop. Subtrop. Gewasse. 246:19-24.

19. Majumder, P. K., and Sinha, G. C. 1972. Studies on the effect of malformation on growth, sex ratio, fruit set and yield of mango. Acta Hortic. 24:230-234.

20. Manicom, B. Q. 1989. Blossom malformation of mango. S. Afr. Mango Grow. Assoc. Yearb. 10:11-12.

21. Marasas, W. F. O., Ploetz, R. C., Wingfield, M. J., Wingfield, B. D., and Steenkamp, E. T. 2006. Mango malformation disease and the associated Fusarium species. Phytopathology 96:667-672.

22. Mullins, E. D., Chen, X., Romaine, P., Raina, R., Geiser, D. M., and Kang, S. 2001. Agrobacterium-mediated transformation of Fusarium oxysporum: An efficient tool for insertional mutagenesis and gene transfer. Phytopathology 91:173-180.

23. Narasimhan, M. J. 1954. Malformation of panicles in mango incited by a species of Eriophyes. Curr. Sci. 23:297-298.

24. Nariani, T. K., and Seth, M. L. 1962. Role of eriophyid mites in causing malformation disease in mango. Indian Phytopathol. 15:231-234.

25. Nash, S. N., and Snyder, W. C. 1962. Quantitative estimations by plate counts of propagules of the bean rot Fusarium in field soils. Phytopathology 73:458-462.
26. Noriega-Cantú, D. H., Téliz, D., Mora-Aguilera, G., Rodriguez-Alcazar, J., Zavaleta Mejía, E., Otero-Colinas, G., and Campbell, C. L. 1999. Epidemiology of mango malformation in Guerrero, Mexico, with traditional and integrated management. Plant Dis. 83:223-228.

27. Ochoa, R., Aguilar, H., and Vargas, C. 1994. Phytophagous Mites of Central America: An Illustrated Guide. CATIE, Turrialba, Costa Rica.

28. Oldfield, G. N., and Proeseler, G. 1996. Eriophyoid mites as vectors of plant pathogens. Pages 259-273 in: Eriophyoid Mites-their Biology, Natural Enemies and Control. E. E. Lindquist, M. W. Sabelis, and J. Bruin, eds. Elsevier Science, Amsterdam.

29. Pena, J. E., Palevsky, E., Otero Colinas, G., Ochoa, R., and Meister, C. W. 2005. Mango bud mite, Aceria mangiferae bionomics and control under Florida conditions. Proc. Fla. State Hortic. Soc. 118:228-234.

30. Ploetz, R. C. 2001. Malformation: A unique and important disease of mango, Mangifera indica L. Pages 233-247 in: Fusarium: Paul E. Nelson Memorial Symposium. B. A. Summerell, J. F. Leslie, D. Backhouse, W. L. Bryden, and W. L. Burgess. eds. The American Phytopathological Society, St. Paul, MN.

31. Ploetz, R. C. 2003. Diseases of mango. Pages 327-363 in: Diseases of Tropical Fruit Crops. R. C. Ploetz, ed. CABI Publishing, Oxford, UK.

32. Ploetz, R. C., and Gregory, N. F. 1993. Mango malformation in Florida: Distribution of Fusarium subglutinans in affected trees, and relationships among strains within and among different orchards. Acta Hortic. 341:388394.

33. Ploetz, R., Zheng, Q. I., Vazquez, A., and Abdel Sattar, M. A. 2002. Current status and impact of mango malformation in Egypt. Int. J. Pest Manage. 48:279-285.

34. Prasad, A., Singh, N., and Singh, S. 1972. Mango malformation-a review of work done at the horticultural research institute, Saharanpur, India. Acta Hortic. 24:227-229.

35. Sao Jose, A. R., Souza, S. E., Vega Pina, A., and Ataide, E. M. 2000. Incidence and severity of mango flower malformation in Bahia State, Brazil. Acta Hortic. 509:765-767.

36. Sayed, M. T. 1946. Aceria mangiferae nov. spec. (Eriophyes mangiferae Hassan M.S.). Bull. Soc. Entomol. 30:7-10.

37. Slykhuis, J. T. 2006. Wheat spot mosaic, caused by a mite-transmitted virus associated with wheat streak mosaic. Can. J. Plant Pathol. 28:206211.

38. Steenkamp, E. T., Britz, H., Coutinho, T. A., Wingfield, B. D., Marasas, W. F. O., and Wingfield, M. J. 2000. Molecular characterization of Fusarium subglutinans associated with mango malformation. Mol. Plant Pathol. 1:187-193.

39. Sternlicht, M., and Goldenberg, S. 1976. Mango eriophyid mites in relation to inflorescence. Phytoparasitica 4:45-50.

40. Summanwar, A. S., and Raychaudhuri, S. P. 1968. The role of eriophyid mite (Aceria mangiferae) in the causation of mango malformation. Indian Phytopathol. 21:463-464.

41. Summanwar, A. S., Raychaudhuri, S. P., and Phatak, S. C. 1966. Association of the fungus Fusarium moniliforme Sheld. with the malformation in mango (Mangifera indica L.). Indian Phytopathol. 19:227-228.

42. Westphal, E., and Manson, D. C. M. 1996. Feeding effects on host plants: Gall formation and other distortions. Pages 231-242 in: Eriophyoid Mites-Their Biology, Natural Enemies and Control. E. E. Lindquist, M. W. Sabelis, and J. Bruin, eds. Elsevier Science B. V., Amsterdam.

43. Whiley, A. W. 1993. Environmental effects on phenology and physiology of mango - a review. Acta Hortic. 341:168-176.

44. Zaher, M. A., and Osman, A. A. 1970. Population studies on mites associated with mango trees in Egypt. Bull. Soc. Entomol. Egypt 54:141-148.

45. Zheng, Q., and Ploetz, R. 2002. Genetic diversity in the mango malformation pathogen and development of a PCR assay. Plant Pathol. $51: 208-216$. 